\title{
Examining the Effects of Organizations Competencies and Opportunistic Behaviors on Firm Performance in a Competitive Environment
}

\author{
Kudret Celtekligil* \\ Fatma Sonmez Cakir** \\ Zafer Adiguzel***
}

Fecha de recibido: 29 de julio de 2021

Fecha de aprobado: 10 de octubre de 2021

Para citar este artículo: Celtekligil, K., Sonmez Cakir, F., \& Adiguzel, Z. (2021) Examining the effects of organizations competencies and opportunistic behaviors on firm performance in a competitive environment. Revista Universidad E Empresa, 23(41),

1-25. https://doi.org/10.12804/revistas.urosario.edu.co/empresa/a.10909

\section{Abstract}

The aim of this research is to show the effects of the relations between capability similarity and opportunistic behaviors and competitiveness and performance from firms. The research provides the basis for capability similarity and opportunistic behaviors. The research was carried out in companies with at least 100 stores, which are centrally located in Istanbul and have a significant share in the service sector. The data were statistically analyzed using the Smartpls 3.2 Package Program. The research showed that the organizations' capabilities and opportunistic behavior influenced their performance and competitiveness.

\footnotetext{
Istanbul Arel University, Istanbul, Turkey. E-mail: kceltekligil@gmail.com ORCID: https://orcid.org/0000-0003-2924-292X

** Bartin University, Bartin, Turkey. E-mail: fsonmez@bartin.edu.tr ORCID: https://orcid.org/0000-0001-5845-9162

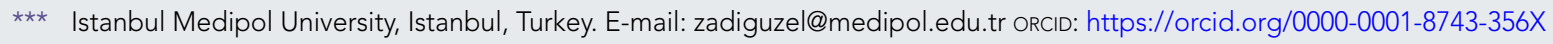


Companies are struggling to ensure both employee satisfaction and customer satisfaction to survive in today's competitive world. Therefore, ensuring competitiveness is objectively the main strategic goal of any company. The research developed a novel framework of competition using a structural perspective and empirical tests the proposed relationships using data from the service sector in Turkey. Since the research was conducted in the service sector and companies located in Istanbul, it contains certain restrictions.

Keywords: Capability similarity; opportunistic behavior; firm competitiveness; firm performance.

\section{Examen de los efectos de las competencias y comportamientos oportunistas de las organizaciones sobre el desempeño firme en un entorno competitivo}

\section{Resumen}

El objetivo de este estudio es mostrar los efectos de las relaciones entre la similitud de capacidades y los comportamientos oportunistas y la competitividad y el desempeño de las empresas. El estudio proporciona una base para la similitud de capacidades y los comportamientos oportunistas. La investigación se llevó a cabo en empresas con al menos 100 tiendas, que están ubicadas en el centro de Estambul y tienen una participación significativa en el sector de servicios. Los datos se analizaron estadísticamente utilizando el programa del paquete Smartpls 3.2. La investigación concluye que las capacidades y el comportamiento oportunista de las organizaciones inciden en su desempeño y competitividad. Las empresas luchan por garantizar tanto la satisfacción de los empleados como la del cliente para sobrevivir en el competitivo mundo actual. Por lo tanto, asegurar la competitividad es objetivamente el principal objetivo estratégico de cualquier empresa. El estudio desarrolló un marco de competencia novedoso usando una perspectiva estructural y una prueba empírica de las relaciones propuestas, empleando datos del sector de servicios en Turquía. Dado que la investigación se realizó en el sector de servicios y empresas ubicadas en Estambul, contiene ciertas restricciones.

Palabras clave: similitud de capacidades; comportamiento oportunista; competitividad de la empresa; desempeño de la empresa.

\section{Revisão dos efeitos das competências e competências oportunistas das organizações no desempenho firme em um ambiente competitivo}

\section{Resumo}

O objetivo deste estudo é mostrar os efeitos das relações entre a similaridade de capacidades e comportamentos oportunistas, a competitividade e o desempenho das empresas. O estudo proposto fornece uma base para similaridade de habilidades e comportamentos oportunistas. A pesquisa foi realizada em empresas com pelo menos 100 lojas, localizadas no centro de Istambul e com participação significativa no setor de serviços. Os dados foram analisados usando o programa Smartpls 3.2 e este programa foi usado para todas as análises estatísticas. Ao final da investigação, observou-se que as capacidades e o comportamento oportunista das organizações afetaram seu desempenho e competitividade. As empresas lutam para garantir a satisfação dos funcionários e clientes para sobreviver no mundo competitivo atual. Portanto, garantir a competitividade é objetivamente o principal objetivo estratégico de qualquer empresa. O estudo desenvolve uma nova estrutura de concorrência usando uma perspectiva estrutural e testa empiricamente as relações propostas usando dados do setor de serviços na Turquia. Uma vez que a investigação foi conduzida no setor dos serviços e em empresas localizadas em Istambul, contém certas restrições.

Palavras-chave: similaridade de capacidade; comportamento oportunista; competitividade da empresa; desempenho da empresa. 


\section{Introduction}

It is arguable that companies that take opportunistic behavior may be in an advantageous position over their competitors. However, in order for companies to take advantage of opportunities, they must have established both their organizational structures and human resources. In other words, together with the management model of the companies, the hierarchical structure within the organization must be managed in good coordination. Otherwise, no matter how good opportunities arise, if the organizational structure is not managed well, it will not be possible for opportunistic behaviors to be successful (Coase, 1937). The basic action in realizing opportunistic behavior is to benefit from the changes occurring in the economy. For this reason, companies should not only analyze the external environment before taking opportunistic behavior actions but also take into account the changes in the economy and examine them within the general environmental analysis. In Williamson's $(1975,1985)$ researches, he emphasized that the decision should be made after analyzing the situation of the competitors and the market and considering the cost factor in the evaluation of the opportunities of the companies. Coordination between all departments is required in order to successfully manage organizational structures and create interaction. By establishing an organizational structure that is open to communication, companies can reach the desired levels of efficiency and performance. Especially for companies in which productivity and efficiency affect performance positively, they can become strong against competitors. Considering the competitive markets, companies that want to be successful in the competition are constantly analyzing and planning in order to achieve their efficiency and performance goals. For companies to be successful in their opportunistic behavior, they also need to improve their skills. If there is a similarity in capability compared to competitors, in this case, using the capability similarities by taking advantage of opportunities will provide them with an advantage over competitors. In addition, companies need to use their abilities to discover opportunities as it will create a cost to produce a product or to provide services to customers in their market (Williamson, 1998). When companies have the necessary physical advantages and workforce resources to realize production, they can gain competitive power against competitors in accessing international markets by giving importance to the development of human resources (Williamson, 1998). Companies that have a competitive advantage but are not large enough can cooperate with the agency for their targeted activities in the international market (Hennart, 2001). One of the most 
important reasons for companies to compete at low cost is their desire to be successful in investments made in international markets. Costs try to be determined by the transaction cost analysis of companies competing in international markets at low costs. When companies want to show a successful graphic both in competitiveness and performance, they should use their capabilities to take advantage of opportunities, considering the cost factor.

In the light of this point of view and within the scope of the research, data collected from companies that are centrally located in Istanbul with a significant share in the service sector and at least 100 stores were analyzed. The research was conducted in the retail sector because they have a desire to be superior in competition and performance by showing opportunistic behaviors in the market they are in, despite the capability similarity to each other. Istanbul was preferred because it is a city with significant economic power and the central management of most companies. Therefore, researchers should consider the limitations of the research. As a result of the analyzes, it can be explained that the capability similarity and opportunistic behaviors of the companies in the merchandising sector have significant effects on both competition and performance.

\section{Literature Review}

\subsection{Capability Similarity}

According to Watkins and Marsick (1997), the learning organization is one that constantly learns and constantly changes itself. Learning in an organization is a continuous and strategic process parallel with the work done and integrated into it. In such an organization, learning helps to create and manage the knowledge that constitutes the intellectual capital of a system. Watkins and Marsick (1997) also identified seven distinct but interrelated dimensions to define individual, team, and organizational level learning organizations. Their 1997's model combines employees and organizational structure for continuous learning and change. The aim of the companies in strategic development is to enhance strategies to reduce the impact of organizational weakness and reveal the core competence that will provide a competitive advantage (Goodarzi et al., 2015). Capability is the skill that the 
organization has learned at a given time and is specific to the organization (Chen, 1996). Beyond the sum of capabilities, capability includes the desire and freedom to act (Kadefors et al., 2020). Chandler (1992) once said that the company's proper capabilities are the most important factor in determining what the company should do within itself and in the market (Madhok, 1996). Scientists working on the capability approach emphasized the economy in production expenditures, while the issue of internal management costs has not been an important topic (Gulbrandsen et al., 2017). Accordingly, the capability approach does not consider the internal change costs included in the assessment of the integration of the new policy (Kikuzawa, 2018). On the other hand, dynamic capabilities are those used to expand, alter, or make routine capabilities (Teece, 2018). When the firm is merged with a supplier's capability base, it becomes much easier to emulate the residue parts to carry out supplier activities within the company (Wu \& Chuang, 2020). Thus, the conceptualization of capability similarity is the stage to which the procurement firm has a dynamic competence that can be employed as an accelerator in the internal learning procedure of how to uncover and mimic the particular capabilities a supplier possesses (Gulbrandsen et al., 2017). In this context, researchers examined how opportunistic behaviors, competitiveness, and performances of companies in the same sector are affected even though their capability similarity is close to each other.

\subsection{Opportunistic Behavior}

Opportunistic behavior is the actions taken by companies to evaluate the situations they discover in line with their own interests to benefit the company (Cuypers et al., 2020). The most important aim of the company in acting is to gain an important advantage in the market by taking advantage of opportunities that will pose a threat to the competitors in the competitive environment of the company. For opportunistic behavior to give an advantage to the company, it is necessary to have skills in using information (Phan \& Ngu, 2018). In some cases, if the company fails to take advantage of the opportunity discovered and cannot act, there may be adverse effects in the process such as incorrect or incomplete information provided, incorrect analysis and evaluation of the information provided, lack of coordination within the company to take advantage of the opportunity, and insufficient human resources (Jap \& Anderson, 2003). In order for companies to behave opportunistically, they should also be taken into account in their economic conditions. Although companies have discovered opportunities within the framework of economic conditions, 
their strengths may not be sufficient to take advantage of these opportunities. Therefore, it is necessary to distinguish between capability similarity and opportunistic behavior. It is likely for there to be a similarity of capability between companies, but what matters is they must act with behaviors that will discover opportunities and provide a competitive advantage in their market. Williamson (1998) stated that in this case, companies need to analyze and evaluate the opportunities they have discovered in terms of taking action for opportunistic behavior, according to their strengths. Because every opportunity does not mean that it is profitable for companies ( $\mathrm{Lu}$ et al., 2016). The important thing is whether the strengths will provide a competitive advantage in terms of benefiting from the opportunities.

Opportunistic behavior has positive and negative consequences for companies in different aspects. For example, if the negative result cannot be opportunistic behavior realized, it is possible that a cost problem will arise because of falling behind the competitors in the competitive environment. Looking at the positive result, an important position in the market can be won over competitors when opportunistic behavior is taken (Suryani \& Pirzada, 2018). It should also be noted that all companies in the market will want to take opportunistic behaviors. The important thing here is to evaluate the opportunities that companies have discovered for themselves, within the economic conditions, and to increase their market share against competitors (Xue et al., 2016).

Correct use of information and information management is very important for companies to be successful in opportunistic behavior actions (Rahman \& Besra, 2020). For this reason, it is necessary to correctly perceive and apply the changes in the economic environment within the organizational structure in taking advantage of the opportunities (Celtekligil, 2020). If there are problems in the hierarchical structure or human resources within the organizational structure, in this case, it will not be possible to benefit from the opportunities, although there are problems in the implementation of the changes in the economic environment. At the same time, opportunities that cannot be exploited due to the problems in the organizational structure will create undesirable costs in the organization (Mattli, 2019).

By comparing the products/services of their competitors in their market with their own products/services, companies can make performance evaluations in line with the expectations of the customers (Dabrowski, 2018). However, while analyzing the performance and 
quality of products/services, they also need to take action to eliminate existing threats in order to take advantage of opportunities (Sharland, 1993). For this reason, the research was carried out within the scope of the research model and the literature on the effect of capability similarity on opportunistic behavior, and the hypothesis has been tested.

H1: Capability similarity has a positive effect on opportunistic behavior.

\subsection{Firm Competitiveness}

Gatignon and Xuereb (1997) revealed that the competitive advantages that direct firms' activities are closely related to the firms' resources. For this reason, the resource-based theory is taken as a basis to examine the competitive advantage. The theory focuses on the firm's resource and competence portfolio and its characteristics (Hitt et al., 2016). According to this theory, companies consist of resources and competencies that provide them with competitive advantages (Barney, 2001). Competitive advantages reflect the capabilities of a firm to outperform its competitors (David \& David, 2016). The fact that companies can compete and perform better than their competitors is also related to their ability to take advantage of the opportunities in their market. Especially if the capabilities of the companies are similar to each other, then how they take advantage of the opportunities becomes even more important. In this case, competitiveness is considered as one of the most important criteria for companies to become a leader in their market compared to their competitors. On the other hand, until the 1980s, the external environment was seen as the most important factor for companies' success (Pratt, 2004). According to this industry-based model, the industry in which the company chose to operate had a stronger influence on performance and profits than the choices managers made within the business. It is known that companies in the same sector generally consist of business groups that produce substitute products (Chikán, 2008). Since these companies have similar talents, they can affect each other in the competition race.

Compared to the general environment, the industrial has a more direct effect on the companies that have strategic competition and a higher-than-average income. The intensity and potential profitability of industry competition is the function of the five forces of competition (Kim et al., 2018). Porter $(1979,1980)$ advocated the Opportunity Approach turning to the external environment and gave an idea about the structures in different competitive envi- 
ronments. He focused on five competitive forces that define attractive aspects in an industry. Each sector has its own unique structure, and these five forces have different degrees of importance according to the sector in which the companies are located. The five competitiveness determine the intensity of industry competition and profitability, and the greatest power or powers are at work in terms of establishing the strategy become extremely important (Juliana \& Nyoman, 2019). The theoretical structure based on industry analysis put forward by Michael Porter is widely used in today's companies for strategic analysis (Hitt et al., 2012). For instance, a company operating in an industry area where new entrants are not threatened will have a low return if it encounters a superior and low-cost replacement product, even if it has a very strong market position (Porter, 2008). Barney (1991) claims that a resource must have four characteristics to gain competitive advantage: value, rarity, inimitability, and substitution. Therefore, gaining competitive power becomes even more important. Especially if companies with similar capabilities take advantage of the opportunities in their market and maintain this situation by gaining competitive power, they gain a significant advantage. Porter (1980) argues that competitive advantage arises from the competitive strategy a firm adopts to act against threats or to take advantage of opportunities in the market. In this context, the ability of companies to compete relates to their ability to take advantage of the opportunities in their market. For this reason, within the scope of the research, it is examined how both capability similarity and opportunistic behaviors of companies affect the firm competitiveness. In the theoretical context, the following hypotheses have been developed:

H2: Capability similarity has a positive effect on firm competitiveness.

H4: Opportunistic behavior has a positive effect on firm competitiveness.

H6: Opportunistic behavior has a mediating effect on the relationship between capability similarity and firm competitiveness.

\subsection{Firm Performance}

Understandings and approaches to performance evaluation are realized as a dynamic process in companies that are constantly developing and changing from past to present. Within that process, it is seen that the performance concepts that have lost their importance, been newly introduced and gained more importance. Briefly, this development process is based 
on the traditional management approach that targets the highest production and profit at the lowest cost, as a requirement of today's competitive conditions, customer satisfaction, employee satisfaction, quality, innovation, etc. expressed as a transition to understandings that focus on very different performance measures (Bayraktar et al., 2017). Firms reassess performance indicators to adapt to increased competition and changing environmental conditions (Kennerley \& Neely, 2002; Daft, 2000). Today, performance measures based only on financial indicators (criteria) are not considered sufficient in evaluating the performance of companies. Especially, balanced scorecard applications are remarkable in cost accounting (Al Maskari, 2019). Research has revealed in this area that performance measures, which are based solely on financial indicators, are insufficient in measuring the factors that are important for companies (Taouab \& Issor, 2019). Therefore, firms must use non-financial indicators along with financial indicators in performance measurements. Traditional performance appraisal methods are one-dimensional, and financial indicators are the ones mostly used. The contributions of financial measurements are also insufficient in dynamic environmental conditions. The predetermined standard form of traditional measurement systems used in all departments does not allow flexibility and eliminates the individual priorities of each department.

Since measurements and reports are made for partners, other interest groups such as employees, suppliers, government, creditors, and industry are not taken into account in traditional systems. Financial performance measures are performance criteria on a company basis; therefore, industry-based criteria on which the company operates are not taken into account. Multidimensional performance evaluation approaches are being developed to address these shortcomings of traditional performance evaluation systems (Wade $\&$ Recardo, 2001). The issue of performance measurement has been handled differently by researchers from many disciplines, according to their own perspectives and approaches (Ibhagui \& Olokoyo, 2018). However, all seem to gravitate around two questions: what are the determinants of organizational performance and how can performance be measured (Neely, 1999; Awwad \& Akroush, 2016). According to Bayraktar et al. (2017), regarding their research on firm performance, the effects of capability similarity and opportunistic behavior on firm performance were examined within the scope of the research. In the theoretical context, the following hypotheses have been developed: 
H3: Capability similarity has a positive effect on firm performance.

H5: Opportunistic behavior has a positive effect on firm performance.

H7: Opportunistic behavior has a mediating effect on the relationship between capability similarity and firm performance.

\section{Methodology}

The survey of this research was conducted within the scope of the research. The data was obtained by using Smartpss 3.2 program, and a descriptive analysis was used in the demographic information. The research was carried out in companies with at least 100 stores, which are centrally located in Istanbul and have a significant share in the service sector. 320 white-collar employees working in different departments of 12 companies answered our survey in accordance with the criteria. 172 male and 148 female white-collar responses were given to our survey. $36.7 \%$ of the participants were in the 30-39 age group, while $49.7 \%$ are in the $40-49$ age group. The number of managers over the age of 50 is $13.1 \%$. $87 \%$ were university graduates. $12 \%$ have a master's degree, and $1 \%$ have a $\mathrm{PhD}$ degree. Factor analysis and reliability/validity analysis were done by using 5 likert-type scales to measure the variables. All analysis results used and interpreted in the research were obtained with the program mentioned. In the first section of the survey, questions about the participants' demographic information and their employees were included. The second part of the survey consisted of scales related to firm performance, firm competitiveness, opportunistic behavior, and capability similarity. In the research, data on endogenous and exogenous variables were collected simultaneously with the same scale. Therefore, the Common Method Bias (смв) effect may be encountered. vIF values are determining factors in determining whether this effect exists or not. VIF indicates whether there is multicollinearity among data, and VIF values less than 5 are preferred. The results obtained are given in Table 1. 


\subsection{Research Goal}

The main goal of this research was to determine the effects of the relationship between firm competitiveness and firm performance with the mediating effect of opportunistic behavior. The reason for choosing the service sector was the intense competition and competitive activities that take place within it. The reason for the selection of white-collar administrative department employees of the sample population was that they are involved in performance orientation in the competitive environment. Accordingly, our aim was to evaluate and analyze the firms in service sector in terms of opportunistic behavior, capability similarity, and performance. A field survey was conducted by using the questionnaire to test the propositions.

\section{Analyses}

The survey consisted of questions representing 4 variables. In the first section of the survey, the demographic information and occupational information of the individuals were given. In the second part, there were questions representing the 4 variables. Capability similarity scale - developed by Gulbrandsen et al. (2017) - and the concepts of opportunistic behavior - developed by Shakeri and Radfar (2017) and Judge and Dooley (2006)—, firm competitiveness - developed by Wu (2008) and Wu et al. (2008) -, and firm performance -developed by Bayraktar et al. (2017)—, were used. Except for firm performance, other variables were evaluated on a 5-point Likert scale as "strongly disagree - strongly agree". The firm performance was evaluated as "very good - very bad", considering the performance criteria of the last three years on a 5-point Likert scale.

\subsection{Research Framework}

The resarch model was applied as independent variables: capability similarity, mediation variable, and opportunistic behavior; dependent variables: firm performance and firm competitiveness. In the research, a quantitative approach was adopted because the data were analyzed in order to specify the relationship between the statistical concepts. The research model 
given in Figure 1 was tested using factor analysis, reliability and validity analysis, descriptive statistics, and mediation effect analysis among the quantitative data analysis methods. The analyzes were started with the factor analysis results, especially the reliability and validity values of the scale. These operations will provide information about the suitability of the data set. The results of all the hypotheses between $\mathrm{H} 1-\mathrm{H} 7$ were obtained from the Smartpls program.

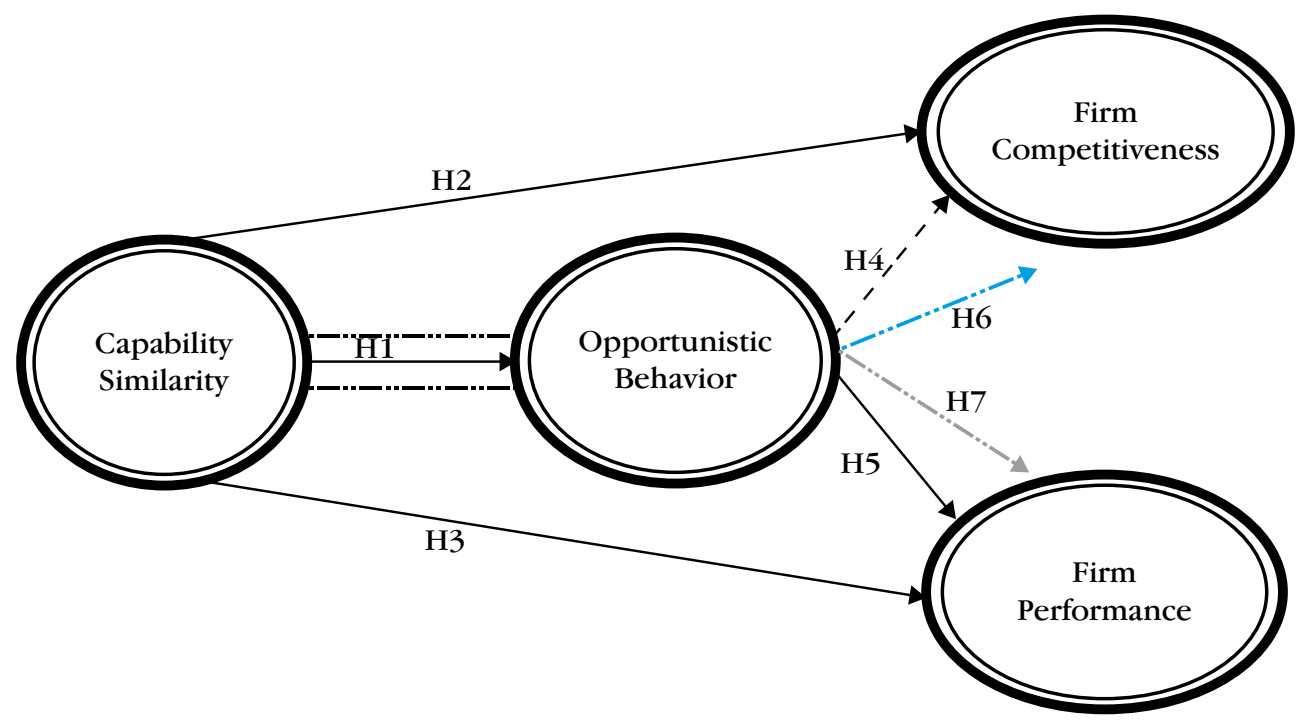

Figure 1. Research Model

Factor analysis was used to determine whether the data was suitable or not and to investigate the construct validity of the scales representing the variables. In the research, the variables were arranged in accordance with the 5-point Likert scale, measured with 20 survey questions. Four questions that did not show the factor distribution in the factor analysis were excluded from the scale because they negatively affected the reliability. Table 1 shows the distribution of 16 questions to 4 factors and their factor loadings and collinearity statistics. 
Table 1. Factor Loadings (FL) and Collinearity Statistics (Variance Inflation Factor, VIF)

\begin{tabular}{|c|c|c|c|}
\hline $\mathrm{FN}$ & & FL & VIF \\
\hline 1 & FP1. Sales are increasing in existing customers. & 0.781 & 2.237 \\
\hline 1 & FP3. The company that I work with achieves financial goals. & 0.776 & 2.364 \\
\hline 1 & FP4. The organization that I work for reaches its profitability target. & 0.862 & 2.571 \\
\hline 1 & FP5. The company I work for reaches the investment return. & 0.765 & 2.030 \\
\hline 1 & FP6. The rate of acquiring new customers is very good. & 0.806 & 2.804 \\
\hline 1 & FP7. The growth in sales revenue in my company is very good. & 0.814 & 2.495 \\
\hline 2 & $\begin{array}{l}\text { FC1. The company I work with responds to changes in the market (such as competition, } \\
\text { market rules) faster than its competitors. }\end{array}$ & 0.856 & 2.168 \\
\hline 2 & FC2. When my company enters any competition, it leaves its competitors behind. & 0.883 & 1.777 \\
\hline 2 & $\begin{array}{l}\text { FC3. The company I work with increases the number of customers by offering customers } \\
\text { higher quality products/services than their competitors. }\end{array}$ & 0.872 & 2.297 \\
\hline 3 & $\begin{array}{l}\text { OB1. The company I work for invests in resources (such as people, equipment, or materials) } \\
\text { to be successful in the competition. }\end{array}$ & 0.790 & 1.967 \\
\hline 3 & $\begin{array}{l}\text { OB2. The company I work for protects its interests strategically in an intensely competitive } \\
\text { environment. }\end{array}$ & 0.725 & 1.803 \\
\hline 3 & $\begin{array}{l}\text { OB3. The policies implemented by the company I work for are in line with the strategic } \\
\text { decisions taken. }\end{array}$ & 0.817 & 3.720 \\
\hline 3 & $\begin{array}{l}\text { OB4. The company I work with organizes its interests according to the practices of the com- } \\
\text { petitors. }\end{array}$ & 0.820 & 3.381 \\
\hline 4 & $\begin{array}{l}\text { CS1. The performance information of the company I work for can be compared with the } \\
\text { performance information of competitors in the execution of the activity. }\end{array}$ & 0.894 & 2.152 \\
\hline 4 & $\begin{array}{l}\text { CS2. The capabilities of the company I work for are suitable to run the activities compared to } \\
\text { the capabilities of the competitors. }\end{array}$ & 0.797 & 1.613 \\
\hline 4 & CS3. Our routines and mechanisms are suited to perform roughly as well as our competitors. & 0.853 & 1.782 \\
\hline
\end{tabular}

FP: Firm Performance, FC: Firm Competitiveness, OB: Opportunistic Behavior,

CS: Capability Similarity, FN: Factor Number.

Factor loadings showing the relations between the expressions and factors vary between 0.725-0.894 for all expressions. These results show that the expressions are compatible with the factors. Whether there is a multicollinearity problem on a scale can be decided by VIF values. If these values are above 5, it indicates that there is a multicollinearity problem in the scale (Hair et al., 2011). When Table 1 is examined, it will be seen that all vif values are below 5 . There is no multicollinearity problem among the scale expressions. 
Table 2. Construct Reliability and Validity Values

\begin{tabular}{lccccc}
\hline \multicolumn{1}{c}{ Variables } & $\begin{array}{c}\text { Number of } \\
\text { Questions }\end{array}$ & $\begin{array}{c}\text { Cronbach Alpha } \\
(\boldsymbol{\alpha}) \text { Values }\end{array}$ & Rho_A & $\begin{array}{c}\text { Composite } \\
\text { Reliability (CR) }\end{array}$ & $\begin{array}{c}\text { Average Variance } \\
\text { Extracted (AVE) }\end{array}$ \\
\hline Capability Similarity (CS) & 3 & .806 & 0.816 & 0.885 & 0.721 \\
\hline Opportunistic Behavior (OB) & 4 & .797 & 0.801 & 0.868 & 0.623 \\
\hline Firm Competitiveness (FC) & 3 & .843 & 0.875 & 0.904 & 0.758 \\
\hline Firm Performance (FP) & 6 & .889 & 0.899 & 0.915 & 0.642 \\
\hline
\end{tabular}

Construct reliability and validity values are given in Table 2 . These values consist of Cronbach's Alpha coefficient and Rho_A coefficient, which give information about the reliability of the scale; Composite (CR), which provides information about the content validity of the scale, and Average Variance Extracted (AVE) values that provide information about the concordance validity. Reliability analysis takes into account the average relationship by measuring the internal consistency of the scales representing the variables. It is considered sufficient to have a Cronbach Alpha over 0.70 in social sciences (Nunnally, 1978; Hair et al., 2000; Büyüköztürk, 2007). Rho_A values are the most important reliability measure for PLS (Dijkstra \& Henseler, 2015). Smartpls 3.2 program also gives composite reliability and average variance, extracted values calculated over factor loads. To reveal the existence of congruence validity in the model, the value obtained should be above 0.50 and the expressions should have AVE values smaller than the $\mathrm{CR}$ values calculated for them, and CR values are expected to be above 0.70 (Sönmez Çakır \& Adıgüzel, 2020). The values given in Table 2 were obtained in reference ranges, so it can be said that the scale has appropriate reliability and validity values.

Correlation analysis was conducted to reveal the degree of relationships between variables. Within the scope of the analysis, both correlations and decomposition validity of four variables with each other were examined. The values obtained are given in Table 3 .

Table 3. Latent Variable (Lv) Correlations, Discriminat Validity

\begin{tabular}{cccccccc}
\hline \multicolumn{3}{c}{ Correlations and Fornell-Larcker Criterion } & \multicolumn{3}{c}{$\begin{array}{c}\text { Heterotrait Monotrait } \\
\text { Ratio (HTMT) }\end{array}$} \\
\hline & CS & FC & FP & OB & CS & FC & FP \\
\hline CS & $0.849^{*}$ & & & & & & \\
\hline FC & 0.328 & $0.871^{*}$ & & & 0.555 & & \\
\hline FP & 0.471 & 0.636 & $0.801^{*}$ & & 0.375 & 0.722 & \\
\hline OB & 0.465 & 0.509 & 0.643 & $0.789^{*}$ & 0.572 & 0.728 & 0.767 \\
\hline
\end{tabular}


Positive correlations were found between variables. The values shown with (*) signs on the table are the values obtained according to Fornell-Larcker Criteria. These values must be the largest value among the row and column values in which they are located, so that the separation validity is ensured according to Fornell-Larcker criteria. Dissociation validity means that expressions are gathered in factors related to them. Likewise, the HTMT ratio also provides information about the discrimination validity. If an HTMT ratio is greater than 0.85 (Clark \& Watson, 1995; Kline, 2011) or 0.90 (Gold et al., 2001), then discriminant validity is not achieved. There is no нтмт value above 0.85 in Table 3 .

After the factor analysis and reliability-validity results, the hypothesis tests established for the model were started. First, the hypotheses between $\mathrm{H} 1$ and H5, in which direct effects were evaluated, are tested. For this, path analysis was done in SmartPLs. The results obtained are given in Table 4.

Table 4. Path Coefficient Result $(\mathrm{H} 1-\mathrm{H} 5)$

\begin{tabular}{cccccccc}
\hline H & Path & $\begin{array}{c}\text { Original } \\
\text { Sample } \\
(\mathbf{O})\end{array}$ & $\begin{array}{c}\text { Sample } \\
\text { Mean } \\
(\mathbf{M})\end{array}$ & $\begin{array}{c}\text { Std. } \\
\text { Deviation } \\
\text { (STDEV) }\end{array}$ & $\begin{array}{c}\text { T } \\
\text { Statistics } \\
\text { (o/sTDEV) }\end{array}$ & $\begin{array}{c}\mathbf{P} \\
\text { Values }\end{array}$ & Decision \\
\hline $\mathrm{H} 1$ & $\mathrm{CS} \rightarrow \mathrm{OB}$ & 0.471 & 0.473 & 0.113 & 4.171 & 0.000 & Accept \\
\hline $\mathrm{H} 2$ & $\mathrm{CS} \rightarrow \mathrm{FC}$ & 0.225 & 0.223 & 0.096 & 2.336 & 0.020 & Accept \\
\hline $\mathrm{H} 3$ & $\mathrm{CS} \rightarrow \mathrm{FP}$ & 0.325 & 0.329 & 0.098 & 3.136 & 0.000 & Accept \\
\hline $\mathrm{H} 4$ & $\mathrm{OB} \rightarrow \mathrm{FC}$ & 0.509 & 0.514 & 0.087 & 5.885 & 0.000 & Accept \\
\hline $\mathrm{H} 5$ & $\mathrm{OB} \rightarrow \mathrm{FP}$ & 0.643 & 0.645 & 0.074 & 8.176 & 0.000 & Accept \\
\hline
\end{tabular}

H1 was accepted because the p-value obtained according to the path analysis results between $\mathrm{cs}$ and ов was $0.020<0.05$. If the $\mathrm{T}$ value given for the path was greater than 1.96, it required $\mathrm{H} 1$ to be accepted. Accordingly, the variable cs has a positive effect on ов. When examined in other hypotheses, all p-value values are less than 0.05 , and all $\mathrm{T}$ values are greater than 1.96. Hypotheses from $\mathrm{H} 1$ to $\mathrm{H} 5$ are accepted.

In the research model, the mediating effects of the opportunistic behavior (oB) variable were analyzed. In the relationship between capability similarity (cs), firm competitiveness (FC) (H6), and firm performance (FP) (H7), the tests showed there is no groove with mediating effects. For this purpose, path analysis was performed in the Smartpus program. Direct 
and indirect effects were obtained; as a result, the presence and extent of the mediator effect were determined.

Table 5. Path Coefficient Result (H6-H7)

\begin{tabular}{cccccccc}
\hline H & Path & $\begin{array}{c}\text { Original } \\
\text { Sample } \\
(\mathbf{O})\end{array}$ & $\begin{array}{c}\text { Sample } \\
\text { Mean (M) }\end{array}$ & $\begin{array}{c}\text { Std. } \\
\text { Deviation } \\
\text { (stDEV) }\end{array}$ & $\begin{array}{c}\text { T } \\
\text { Statistics } \\
\text { (o/stDEV) }\end{array}$ & $\begin{array}{c}\mathbf{P} \\
\text { Values }\end{array}$ & Decision \\
\hline $\mathrm{H} 6$ & $\mathrm{CS} \rightarrow \mathrm{OB} \rightarrow \mathrm{FC}$ & 0.240 & 0.243 & 0.071 & 3.357 & 0.001 & Accept \\
\hline $\mathrm{H} 7$ & $\mathrm{CS} \rightarrow \mathrm{OB} \rightarrow \mathrm{FP}$ & 0.303 & 0.306 & 0.085 & 3.567 & 0.000 & Accept \\
\hline
\end{tabular}

Table 5 gives the Path values for which we will determine the effect of the mediation variable. First, there is a suitable path between $\mathrm{Cs} \rightarrow \mathrm{OB} \rightarrow \mathrm{FC}$ variables $(\mathrm{P}$-value $0.001<0.05$ ). In addition, the $\mathrm{T}$ statistics value (3.357) is higher than 1.96, and this creates the result of accepting H6. Accordingly, the ов variable has a positive path effect between Cs and FC. There is a way between the three variables as shown in the research model. There is also a suitable path between $\mathrm{Cs} \rightarrow \mathrm{OB} \rightarrow \mathrm{FB}$ variables ( $\mathrm{P}$-value $0.000<0.05$ ). The $\mathrm{T}$ statistics value (3.567) is also greater than 1.96, which results in $\mathrm{H} 7$ being accepted. Accordingly, the oB variable has a positive path effect between Cs and FB. There is a way between the three variables, as shown in the research model. The important thing here is the mediation effect value of ов among the variables. For this, direct, indirect, and total effect values were examined in the model. For this purpose, variance accountant for the vaf value was examined. The vaf value is used to calculate the ratio of indirect impact to total impact (Nitzl \& Hirsch, 2016). If vaF values are below 20\%, zero mediator effect is mentioned, while vaf values between 20 and $80 \%$ mean partial mediator effect. vaf above $80 \%$ means full mediator effect (Hair et al., 2017).

Table 6. Test of Mediation by Bootstrapping Approach

\begin{tabular}{ccccccc}
\hline $\mathbf{H}$ & Paths & $\mathbf{a}$ & $\mathbf{b}$ & $\mathbf{c}$ & $\begin{array}{c}\text { vaf } \\
\mathbf{a} * \mathbf{b} / \mathbf{(} \mathbf{*} \mathbf{b}+\mathbf{c})\end{array}$ & Decision \\
\hline $\mathrm{H} 6$ & $\mathrm{CS} \rightarrow \mathrm{OB} \rightarrow \mathrm{FC}$ & 0.471 & 0.509 & 0.225 & 0.52 & Accept \\
\hline $\mathrm{H} 7$ & $\mathrm{CS} \rightarrow \mathrm{OB} \rightarrow \mathrm{FP}$ & 0.471 & 0.643 & 0.325 & 0.48 & Accept \\
\hline
\end{tabular}

The vaf value was calculated from the effects between variables. The $a$ value gives the path coefficients between the first and the second variable, the $b$ value between the second and the third variable, and the $c$ value between the first and the third one. While a 
* $b$ in the formula gives the total indirect effect, $a * b+c$ shows the total effect value. The ratio of indirect effect to total effect gives the vaf value. A vaF value between 20 and $80 \%$ shows that the tests given in both $\mathrm{H} 6$ and $\mathrm{H} 7$ are correct, and the ов variable has a partial mediator effect among the other variables. As a result of the research, all hypotheses are supported within the scope of the research model. According to the analysis results, the positive effect between $\mathrm{H} 1$ and $\mathrm{H} 5$ has been proved, and the mediation effect of the ов tested with $\mathrm{H} 6$ and $\mathrm{H} 7$ hypotheses was revealed.

\section{Discussion}

Although this research was in the service sector, which has a high level of intense competition and has a dynamic structure, there are limitations that should be considered in future research. First, the research model should be expanded with various concepts in other industries (e.g., production, information technologies), markets (e.g., cultural differences, national-international markets), and organizational structures. Second, it will be useful to categorize the capabilities of the firms in the service sector according to their service diversity and organizational structure. In particular, the discovery of common findings and complementary abilities and behaviors may be useful in future studies. For one company to compete, all employees must have the competencies they have in their organizational structure. To achieve this, it is necessary to successfully implement the managerial process defined in managerial terms (Eisenhardt \& Martin, 2000; Teece et al., 1997). It means that companies can be successful in competition and, as a result, their performance is better than competitors.

While opportunistic behavior and capability similarity variables are interrelated, each new structure to be made within the organization must continue with a better structuring without disturbing the organizational behavior and capabilities of the firm, rather than constantly improving itself. Evaluation and opportunities used by organizations depend on the successful application of their abilities. The successful implementation of capabilities depends on the fact that the organizations constantly focus on learning and, at the same time, the mechanisms in the organizational structure can act together (Nonaka, 1994; 
Nippa et al., 2011). Gulbrandsen et al. (2017) concluded in their research that capability similarity negatively affected internal-to-firm transaction costs. In other words, decreasing costs can give companies a competitive advantage and strengthen the competitiveness of the company. The research results help to explain that capability similarity positively affects firm performance and competitiveness. On the other hand, while there are many sellers and buyers in terms of competition in the market in which companies act in opportunistic behavior, the product quality and performance can be easily controlled, and the opportunities to enter the market are decreasing. However, one situation worth mentioning is opportunism increment when market conditions begin to differ. Companies always look for opportunities in their market or in the market they intend to enter for the first time because they are actually pursuing their own interests by looking for opportunities. Companies want to be in an advantageous position in the market by discovering the most suitable opportunities for them. At the same time, when companies discover opportunities and implement the necessary strategies, their level of competitiveness and their performance are positively affected. In addition, there is a need for further research on the questions that represent the similarity of capability in the future because the new current of artificial intelligence in the 5.0 industry will be subject to its superiority. Therefore, companies will need to renew the questions representing the variables. This research provides a perspective to expand and enhance the understanding of skills and behavioral processes that influence the competitiveness of firms for future research. At the same time, it is believed that it should be aimed to make more contribution to the literature by making comparative analysis in future studies.

\section{Conclusion}

As a result of the findings obtained from the firms in the service sector where there is intense tempo, firms that use the capabilities well and evaluate the opportunities in terms of competitiveness and performance are successful. It is a fact that in the service sector, there is a standard skill, and continuing knowledge and competitiveness in the same system is not easy nor impossible. Especially, it can be explained that companies in the retailing sector, which has an important position in the service sector, have positive effects on their 
performance and competitiveness when they benefit from the similarity of capability and opportunistic behavior. Since in the service sector, which has a highly dynamic structure, customers always want to meet new concepts and life-facilitating innovations, firms have to constantly renew and improve their capabilities and knowledge capacities. Innovation and opportunistic behaviors of organizations have the effect of improving their competitiveness and performance. As a result of the data obtained from the 320 white-collar working in the service sector, the company has a positive impact on competitiveness and company performance. Especially in the mediation variable effect of the opportunistic feature, the competitiveness and performance of the companies are positive. These findings contribute to the current literature in many important ways. First, our findings provide new evidence for the theoretical development of the relations between organizations, competitiveness, and performance. The fact that the firms in the service sector do not fall back from competition and that their performances are permanently improved are directly proportional to their organizational capabilities. At the same time, it shows the importance given to the ability of organizations to be successful in the competitive environment strategic and opportunistically. It is likely that the organizations that use their capabilities well are strategically leading companies in their market. Having opportunistic behavior inspires the organization in terms of diversity. In the analysis results, the fact that the organizations have opportunistic behaviors supports their more competitive performance (Goluchowicz \& Blind, 2011). In previous research, it has been investigated that the performance of organizations in terms of their services is positive or negative. The findings of this research, by analyzing the impact of capability and opportunism on competitiveness performance, improve the understanding of future studies. For this reason, it will be possible to contribute more to the literature with research in different industry structures in the future. In the research, there is a certain limitation as we only examine companies that have stores in the service sector. Comparative analyzes to be made between companies in the same sector but in different countries will contribute more.

\section{References}

Al Maskari, G. S. (2019). The impact of intellectual capital and balanced scorecard implementation on firm performance (Doctoral dissertation, University of Bradford, United 
Kingdom). Available from https://bradscholars.brad.ac.uk/bitstream/handle/10454/17390/ al\%20maskari\%2c\%20g.s.s.pdf?sequence $=1 \&$ isAllowed $=y$

Awwad, A., \& Akroush, M. N. (2016). New product development performance success measures: an exploratory research. EuroMed Journal of Business, 11(1), 2-29. https://doi. org/10.1108/емјв-12-2014-0043

Barney, J. (1991). Firm resources and sustained competitive advantage. Journal of Management, 17(1), 99-120. https://doi.org/10.1177/014920639101700108

Barney, J. B. (2001). Resource-based theories of competitive advantage: a ten-year retrospective on the resource-based view. Journal of Management, 27(6), 643-650. https://doi. org/10.1177/014920630102700602

Bayraktar, C. A., Hancerliogullari, G., Cetinguc, B., \& Calisir, F. (2017). Competitive strategies, innovation, and firm performance: an empirical study in a developing economy environment. Technology Analysis \& Strategic Management, 29(1), 38-52. https://doi.org/10.108 0/09537325.2016.1194973

Büyüköztürk, Ş. (2007). Sosyal bilimler için veri analizi el kitabı: istatistik, araştırma deseni, sPss uygulamalar ve yorum. Pegem A Yayınc1lı.

Celtekligil, K. (2020). Transaction cost theory. In H. Dincer \& S. Yüksel (Eds.), Strategic priorities in competitive environments. Contributions to management science (pp. 141-154). Springer. https://doi.org/10.1007/978-3-030-45023-6_8

Chandler, A. D. (1992). Organizational capabilities and the economic history of the industrial enterprise. Journal of Economic Perspectives, 6(3), 79-100. Available from https://www. jstor.org/stable/2138304

Chen, R. (1996). Technological expansion: the interaction between diversification strategy and organizational capability. Journal of Management Studies, 33(5), 649-666. https:// doi.org/10.1111/j.1467-6486.1996.tb00813.x

Chikán, A. (2008). National and firm competitiveness: a general research model. Competitiveness Review: An International Business Journal, 18(1/2), 20-28. https://doi. org/10.1108/10595420810874583

Clark, L. A., \& Watson, D. (1995). Constructing validity: basic issues in objective scale development. Psychological Assessment, 7(3), 309-319. https://doi.org/10.1037/1040-3590.7.3.309

Coase, R. H. (1937). The nature of the firm. Economica, 4(16), 386-405. https://doi. org/10.1111/j.1468-0335.1937.tb00002.x

Cuypers, I., Hennart, J. F., Silverman, B., \& Ertug, G. (2020). Transaction cost theory: past progress, current challenges, and suggestions for the future. Academy of Management Annals, 15(1), 111-150. https://doi.org/10.5465/annals.2019.0051 
Dabrowski, D. (2018). Sources of market information, its quality and new product financial performance. Engineering Economics, 29(1), 115-122. https://doi.org/10.5755/j01. ee.29.1.13405

Daft, R. L. (2000). Organization theory and design. South Western College Publishing.

David, F., \& David, F. R. (2016). Strategic management: a competitive advantage approach, concepts and cases. Pearson-Prentice Hall.

Dijkstra, T. K., \& Henseler, J. (2015). Consistent partial least squares path modeling. Management Information Systems Quarterly, 39(2), 297-316. https://doi.org/10.25300/ MISQ/2015/39.2.02

Eisenhardt, K., \& Martin, J. (2000). Dynamic capabilities: what are they? Strategic Management Journal, 21(10-11), 1105-1121. Available from https://www.jstor.org/stable/3094429

Gatignon, H., \& Xuereb, J. M. (1997). Strategic orientation of the firm and new product performance. Journal of Marketing Research, 34(1), 77-90. https://doi.org/10.1177/002224379703400107

Gold, A. H., Malhotra, A., \& Segars, A. H. (2001). Knowledge management: an organizational capabilities perspective. Journal of Management Information Systems, 18(1), 185-214. https://doi.org/10.1080/07421222.2001.11045669

Goluchowicz, K., \& Blind, K. (2011). Identification of future fields of standardisation: an explorative application of the Delphi methodology. Technological Forecasting and Social Change, 78(9), 1526-1541. https://doi.org/10.1016/j.techfore.2011.04.014

Goodarzi, M., Sheikhi, M., \& Shabani, M. (2015). A framework for strategy development in small companies the case study of a telecommunication firm. Journal of Applied Environmental and Biological Sciences, 5(11), 223-230.

Gulbrandsen, B., Lambe, C. J., \& Sandvik, K. (2017). Firm boundaries and transaction costs: the complementary role of capabilities. Journal of Business Research, 78, 193-203. https:// doi.org/10.1016/j.jbusres.2016.12.015

Hair, F., Hult, M., Ringle, C., \& Sarstedt, M. (2017). A primer on partial least squares structural equation modeling (PLS-SEM). SAGE Publications.

Hair, J. F., Ringle, C. M., \& Sarstedt, M. (2011). PLs-SEM: 1ndeed a silver bullet. Journal of Marketing Theory and Practice, 19(2), 139-152. https://doi.org/10.2753/MTP1069-6679190202

Hair, J. F., Robert, P. B., \& David, J. O. (2000). Marketing research, international edition. Irwin McGraw-Hill.

Hennart, J. F. (2001). Theories of the multinational enterprise. In A. M. Rugman (Ed.), The Oxford handbook of international business. Oxford University Press. https://doi.org/10.1093/ oxfordhb/9780199234257.003.0005 
Hitt, M. A., Ireland, R. D., \& Hoskisson, R. E. (2012). Strategic management cases: competitiveness and globalization. Cengage Learning.

Hitt, M. A., Xu, K., \& Carnes, C. M. (2016). Resource based theory in operations management research. Journal of Operations Management, 41, 77-94. https://doi.org/10.1016/j. jom.2015.11.002

Ibhagui, O. W., \& Olokoyo, F. O. (2018). Leverage and firm performance: new evidence on the role of firm size. The North American Journal of Economics and Finance, 45, 57-82. https://doi.org/10.1016/j.najef.2018.02.002

Jap, S. D., \& Anderson, E. (2003). Safeguarding interorganizational performance and continuity under ex post opportunism. Management Science, 49(12), 1684-1701. https://doi. org/10.1287/mnsc.49.12.1684.25112

Judge, W. Q., \& Dooley, R. (2006). Strategic alliance outcomes: a transaction-cost economics perspective. British Journal of Management, 17(1), 23-37. https://doi.org/10.1111/j.14678551.2005.00441.x

Juliana, J. P. E., \& Nyoman, Y. N. (2019). Factors influencing competitiveness of small and medium industry of Bali: Porter's five forces analysis. Russian Journal of Agricultural and Socio-Economic Sciences, 89(5), 45-54. https://doi.org/10.18551/rjoas.2019-05.06

Kadefors, R., Wikström, E., \& Arman, R. (2020). The capability of organizations to manage delayed retirement. Journal of Organizational Effectiveness: People and Performance, 7(1), 38-51. https://doi.org/10.1108/JOEPP-06-2019-0047

Kennerley, M., \& Neely, A. (2002). Business performance measurement: theory and practice. Cambridge University Press.

Kikuzawa, K. (2018). Rational failure of the firm: transaction costs economics and dynamic capabilities (Faculty of Business and Commerce, Keio University, Tokyo). Available from https://www.researchgate.net/publication/324771516_Rational_Failure_of_the_Firm_ Transaction_Costs_Economics_and_Dynamic_Capabilities

Kim, D. J., Hebeler, J., Yoon, V., \& Davis, F. (2018). Exploring determinants of semantic web technology adoption from IT professionals' perspective: industry competition, organization innovativeness, and data management capability. Computers in Human Behavior, 86, 18-33. https://doi.org/10.1016/j.chb.2018.04.014

Kline, R. B. (2011). Convergence of structural equation modeling and multilevel modeling. In The SAGE handbook of innovation in social research methods (pp. 562-589). https://doi. org/10.4135/9781446268261.n31

Lu, W., Zhang, L., \& Zhang, L. (2016). Effect of contract completeness on contractors' opportunistic behavior and the moderating role of interdependence. Journal of Construction 
Engineering and Management, 142(6), 1-10. https://doi.org/10.1061/(ASCE)Co.19437862.0001110

Madhok, A. (1996). The organization of economic activity: transaction costs, firm capabilities, and the nature of governance. Organization Science, 7, 577-590. Available from https:// www.jstor.org/stable/2635293

Mattli, W. (2019). Darkness by design: the hidden power in global capital markets. Princeton University Press.

Neely, A. D. (1999). The performance measurment revolution: why now and what new? International Journal of Operations and Production Management, 3(2), 205-228. https:// doi.org/10.1108/01443579910247437

Nippa, N., Pidun, U., \& Rubner, H. (2011). Corporate portfolio management: appraising four decades of academic research. Academy of Management Perspectives, 25(4), 50-66. Available from https://www.jstor.org/stable/23208293

Nitzl, C., \& Hirsch, B. (2016). The drivers of a superior's trust formation in his subordinate. Journal of Accounting \& Organizational Change, 12(4), 472-503. https://doi.org/10.1108/ JAOC-07-2015-0058

Nonaka, I. (1994). A dynamic theory of organizational knowledge creation. Organization Science, 5, 14-37. Available from https://www.jstor.org/stable/2635068

Nunnally, J. C. (1978). Psychometric theory. McGraw-Hill.

Phan, H. P., \& Ngu, B. H. (2018). An examination of social and psychological influences on academic learning: a focus on self-esteem, social relationships, and personal interest. Social Psychology of Education, 21(1), 51-73. https://doi.org/10.1007/s11218-017-9407-9

Porter, M. (1979). How competitive forces shape strategy. Harvard Business Review, 57(2), 137-145. Available from https://hbr.org/1979/03/how-competitive-forces-shape-strategy

Porter, M. (1980). Competitive strategy: techniques for analyzing industries and competitors. Free Press.

Porter, M. (2008). The five forces that shape competitive strategy. Harvard Business Review, 86(1), 78-93. Available from https://hbr.org/2008/01/the-five-competitive-forces-that-shape-strategy

Pratt, Z. L. (2004). An investigation of the relationships between external environment, mission and strategy, leadership, organizational culture, and performance. Michigan State University. 
Rahman, H., \& Besra, E. (2020). Explicating failure among nascent entrepreneurs in West Sumatra: the nexus of psycho-economic factors and opportunistic behavior. Journal of Entrepreneurship, Management and Innovation, 16(2), 37-66. https://doi. org/10.7341/20201622

Shakeri, R., \& Radfar, R. (2017). Antecedents of strategic alliances performance in biopharmaceutical industry: a comprehensive model. Technological Forecasting and Social Change, 122, 289-302. https://doi.org/10.1016/j.techfore.2016.01.003

Sharland, A. P. (1993). International outsourcing: an empirical of the role of transactions costs and competitive advantage in the international buyer/supplier relationship (Doctoral dissertation, Florida State University, Florida, United States of America).

Sönmez Çakır, F., \& Adıgüzel, Z. (2020). Examining of organizational citizenship behaviors and employee involvement in transformational leadership and organization support: a research on white collar bank employees. Journal of Business Research-Turk, 12(1), 111125. https://doi.org/10.20491/isarder.2020.831

Suryani, A., \& Pirzada, K. (2018). Analysis of opportunistic behavior of management to company performance. Polish Journal of Management Studies, 18(1), 379-388. https://doi. org/10.17512/pjms.2018.18.1.28

Taouab, O., \& Issor, Z. (2019). Firm performance: definition and measurement models. European Scientific Journal, 15(1), 93-106. https://doi.org/10.19044/esj.2019.v15n1p93

Teece, D. J. (2018). Business models and dynamic capabilities. Long Range Planning, 51(1), 40-49. https://doi.org/10.1016/j.lrp.2017.06.007

Teece, D. J., Pisano, G., \& Shuen, A. (1997). Dynamic capabilities and strategic management. Strategic Management Journal, 7, 509-533. Available from https://www.jstor.org/stable/3088148

Wade, D., \& Recardo, R. J. (2001). Corporate performance management: how to build a better organization through measurement-driven strategic alignment. Routledge.

Watkins, K. E., \& Marsick, V. J. (1997). Dimensions of the learning organization questionnaire. Warwick, RI: Partners for the Learning Organization.

Williamson, O. E. (1975). 1975 Markets and hierarchies: analysis and antitrust implications. Free Press.

Williamson, O. E. (1985). The economic institutions of capitalism. Free Press.

Williamson, O. E. (1998). Transaction cost economics: How it works; where it is headed. Economist, 146, 23-58. https://doi.org/10.1023/A:1003263908567 
Wu, C. K., \& Chuang, Y. M. (2020). Game theoretic strategies for supplier capability assessment and manufacturing order allocation. Journal of Risk Analysis and Crisis Response, 10(4), 121-129. https://doi.org/10.2991/jracr.k.201014.002

Wu, L. Y., Wang, C. J., Chen, C. P., \& Pan, L. Y. (2008). Internal resources, external network, and competitiveness during the growth stage: a study of Taiwanese high-techventures. Entrepreneurship Theory and Practice, 32(3), 529-549. https://doi.org/10.1111/j.15406520.2008.00239.x

Wu, W. P. (2008). Dimensions of social capital and firm competitiveness improvement: the mediating role of information sharing. Journal of Management Studies, 45(1), 122-146. https://doi.org/10.1111/j.1467-6486.2007.00741.x

Xue, J., Yuan, H., \& Shi, B. (2016). Investigating partners' opportunistic behavior in joint ventures in China: the role of transaction costs and relational exchanges. Journal of Business Research, 69(12), 6067-6078. https://doi.org/10.1016/j.jbusres.2016.06.011 